\title{
Fetishism as Theatrical Device in Nelson Rodrigues's Os Sete Gatinhos
}

\author{
ISADORA GREVAN DE CARVALHO \\ Rutgers University-Newark
}

\begin{abstract}
In this essay, I examine the concept of fetish and how it manifests itself as Brazilian social structures in the theater of Nelson Rodrigues. I offer a particularly detailed study offetish in Rodrigues's Os Sete Gatinhos. Here fetish serves to illuminate gender relations and the patriarchal family as a cultural myth to be deconstructed, as well as working to reveal the connections between space, bodies, performativity, and power in Brazilian society.
\end{abstract}

Keywords: Brazilian theater; modernism; psychoanalysis; masquerade; Gilberto Freyre

Almost single-handedly, Nelson Rodrigues was responsible for catapulting Brazilian theater into the twentieth century. Before him, most plays being performed in the country consisted of boulevard comedies, European pieces put on by foreign acting companies, and chanchadas. ${ }^{1}$ This is so much the case that by writing and staging plays for the purpose of more than light-hearted entertainment, Rodrigues literally reinvented Brazilian dramaturgy. Furthermore, he introduced novelties in stage-set design and narrative style, in addition to incorporating colloquial language and characters representative of different social classes, that belong to very specific but previously ignored

\footnotetext{
${ }^{1}$ The chanchada is a Brazilian type of musical comedy very popular in the 1930s both in theater and film. The name is derived from a Spanish slang term meaning "trash" and suggests a culturally poor form of entertainment.
} 
sectors of Brazilian society. The changes he introduced into Brazilian theater can be compared in depth and scope to the modernist movement in literature and in the arts, which had started at least one decade earlier, spearheaded by writers and artists such as Oswald de Andrade, Tarsila do Amaral and Manuel Bandeira.

As a result of the historic performance of Vestido de Noiva in 1943 by the amateur acting group Os Comediantes, for example, the emphasis on developing serious, well-trained, professional theater companies and promoting new Brazilian playwrights who would focus on subjects of national concern, gained significant momentum. The staging of this play by the expressionist Polish-born director Zbigniew Marian Ziembiński likewise significantly influenced the way future Brazilian theater projects would be viewed and performed. According to David George, Os Comediantes provided an important "laboratory, where experiments in stagecraft took place, a school, as it were, of the dramatic arts" (8). The confluence of a group of actors eager to elevate Brazilian theater, Ziembiński's introduction of new ideas then in vogue in Europe, the work of the stage designer Santa Rosa, and the play itself, marked an astounding theatrical combination of artistry and experimentation with a distinctively Brazilian flair. Décio de Almeida Prado would later write that with this performance, the theater became "universal" in the way other art forms had long been: "Nelson Rodrigues representava para o Palco que trouxeram Villa-Lobos à música, Portinari para a pintura e Carlos Drummond de Andrade para poesia" (21).

It can be argued, however, that the persona and popularity of Rodrigues have often originated from a misguided or even erroneous interpretation of his writings and commentary, samples of which were often deliberately taken out of context in order to shock or cause laughter. ${ }^{2}$ A closer examination reveals much more substance in Rodrigues's social commentary than any anecdotal reactions or pornographic images (in connection with his often unabashed portrayal of sexuality) might provide. Sexuality, particularly in his plays, is never gratuitous. On the contrary, it is most frequently depicted as the expression of repressed desires in the lives of individuals and families or as a reflection of violence against women or a manifestation of repressed desires for revenge. Not

\footnotetext{
${ }^{2}$ Despite the considerable acclaim he has received over the years, Rodrigues's career as a journalist, fiction writer, and playwright has consistently divided critics (Castro 8).
} 
Grevan

surprisingly, some of his plays have often been considered pornographic even though the author himself often publicly expounded on the value of chastity. $\mathrm{He}$ would at times contradict the most immediate shocking elements of his theater to justify and accentuate his use of sexual themes as a means of exposing other factors inherent to the human condition in general and within Brazil in particular.

Rodrigues's unique style may in fact pose some knotty challenges for the reader/audience. The question remains how to stage any of his plays or make one into a movie without falling into the trap of portraying sexuality as only pornographic or as expressing a rather animalistic side of humanity at its lowest instead of depicting sexuality in a more complex and controversial manner (perhaps playing around with these two starkly-contrasting manifestations). In order to engage successfully with Rodrigues's work, it is essential never to downplay the contradictions, complexities, and often overly-condensed paradoxes that are portrayed in the themes, scenes and material realities, which are features also expressed in his persona as a journalist and author. Hence, an action or word often contains an opposite intention or desire, or a parallel unconscious wish that goes counter to what is dramatized on stage. Furthermore, Rodrigues likes to represent dualities in order to contest or complicate them.

As I will develop further in my analysis of Os Sete Gatinhos, the condensed aspect of the fetish as structure contains within itself all the opposing and ambiguous forces mentioned above, which could ultimately help us decipher some of the major complexities in Rodrigues's plays. The unpacking of the formation and manifestation of fetish can give us new insights into his work as well as serve as an aid in opening up new possibilities for interpretation and performance.

Os Sete Gatinhos, though classified by Sábato Magaldi as a "Tragédia Carioca" situated in Rio de Janeiro, takes place within the confines of a family home with no apparent reverberations within the society at large. At the end of the play, the patriarch of the home is ultimately destroyed and the women are able to achieve limited power in the process of destroying him. However, the ending is neither optimistic nor does it offer the family any possibility of redemption in the context of society's Catholic mores, a looming psychological presence. Although exerting power in the home, Rodrigues may be arguing in the play that the women will not ultimately command the same authority in 
society. Furthermore, characters are largely motivated by perverse obsessive attachments that lead them to egotistical gain to the detriment of the family unit.

Furthermore, the obsessive relationships established between the characters and "objects" of their choosing are destined to be maintained, since when one of these objects is mutilated and eliminated others are chosen to replace them, which creates a vicious cycle of fetishistic embodiments paradoxically tied to familial attachments and societal mores. Rather than a duality, the repetitive patterns of unmasking and destructions in the play turn into never-ending, never-resolved, truth-searching labyrinths that are materialized and condensed within the fetishes.

Before discussing the fetishistic strategy at work in Rodrigues's theater, it is useful to provide a brief summary of the play. Classified as a comedy, it destabilizes theatrical forms and styles. Rodrigues constantly undermines his audience's expectations through confusion and the insertion of comedic undertones within scenes of death and despair, vernacular language from Rio de Janeiro, and clichéd carioca characters. Dialogues that at first sound typical of oral communication, are frequently chopped and minimal, removing their realistism. Even the rubrics add a personal and ironic twist to the scene. In the rubrics right before the play starts, Rodrigues uses expressions such as "diga-se de passagem," "um bigodinho aparado e cínico," or "medalhinha de um santo qualquer" to describe the interaction between Aurora and Bibelot (839). If the rubrics serve as a stage direction for the play's performance, what do these colloquial, matter of fact expressions add? This destabilizing phenomenon, typical of Rodrigues's plays, works to destabilize many facets of his theater, further contributing to the fetishistic strategy. The family unit, for example, although representing an archetypal Brazilian family of Freyrian proportions, is also a family with no stability to begin with, needing the constant efforts of the anxious patriarch to sustain it.

Os Sete Gatinhos revolves around a married Mr. Noronha, the father of five daughters. Mr. Noronha feels socially humiliated in his government job as a messenger boy for the Brazilian House of Representatives. To compensate for his feeling of inferiority at work, he embodies and acts out the role of an authoritarian patriarch at home. Furthermore, he exhibits psychic powers in subjugating his wife and daughters to his orders through fear and threats while channeling the spirit of D. Pedro II's doctor. This spiritual relationship is, 
Grevan

nonetheless, only manifested during family gatherings. The authenticity of these episodes is eventually questioned since it appears to have been invented for the purpose of controlling the women of the family while providing a fetish with even greater cultural weight, the fetish of superstition. This comes in ironic contrast to the fetish of the virgin marriage in the Roman Catholic church. Before the actions of the play begins, Mr. Noronha's youngest daughter, Silene, is suddenly ferried away to a boarding school to escape what the father believes to be the inherently destructive nature of the family due not only to its lower-class condition, but to a belief that someone has cast a spell on them to prevent his daughters from ever getting married. At one point, for example, he exclaims: "Qualquer vagabunda casa?!" (842), alluding to the fact that what is preventing his daughters from marrying is in fact a curse.

One later finds out that what actually prevents the daughters from marrying is the father himself, insofar as his controlling and violent presence disturbs all their relationships with men. In fact, the father later affirms that he desires the wedding and not the virginity or purity of his daughters before marriage, contradicting some of his previous claims on the values of chastity. Contrary to the father's multiple statements on morality, four of his daughters are forced to become prostitutes to make money to buy a trousseau for Silene, who is now his only virgin daughter.

Meanwhile, the spirit of Dr. Barbosa Coutinho, D. Pedro II's deceased doctor, is said to appear to Noronha, delivering the message that a man who "chora de um olho só" (843) is going to take his daughter's virginity. Noronha pronounces this at the beginning of the play as an omen of what is to come. The possibility of his family's "salvation" by way of Silene's virginal purity and marriage is threatened by this prediction. As the play unfolds, however, Silene is expelled from school for killing a cat pregnant with seven kittens. She beats it to death right in front of the whole student body, making her punishment less the result of an omen, and more a psychological response to her family's controlling behavior.

The seven kittens of the title directly mirror the seven members of Silene's own family. Abandoned to their fate, the kittens are conceived through violent means under the threat of destruction. Silene's violent act stems from a combination of guilt and an act of rebellion against her plight. When she returns home, she shamelessly announces that she has been impregnated by Bibelot, a 
prototype of the typical malandro - a married man who also happens to be her sister Aurora's lover. As Ronaldo Lima Lins argues: "we perceive, for example, that Bibelot is roguish and gigolo-like, knows how to take advantage of situations, and portrays himself as self-assured and daring" (165). Dr. Bordalo, the family doctor, examines Silene and confirms the pregnancy.

This revelation is so powerful that it triggers the downward spiral of the entire family. Noronha sees this event as marking the impossibility of redemption of the family in any form. In his eyes, the solution to this problem is to kill the man with "one eye only" and turn the household into a brothel, at which time the whole neighborhood will learn that, at the father's instigation, his four other daughters have become prostitutes. He has gotten tired of hiding behind masks and hypocrisies, and he himself declares that his daughters' job is but a masquerade (845). The father ends up killing Bibelot, believing he is the oneeyed man. Right before Bibelot dies, however, two tears drop from both of the murdered man's eyes, proving that he is not the man who cries from one eye. Finally, at the end of the play, the women stage a rebellion against their father and mercilessly stab him to death.

Sábato Magaldi, commenting on some of the difficulties encountered in interpreting Rodrigues's plays, states that:

Nelson's work has produced ... the most contradictory stagings. No director approaches his plays with the aim of merely carrying out his stage directions. Nelson Rodrigues' creativity stimulates the imagination of all those involved in the production. It is fortunate, I believe, that there is no fixed interpretative style for Shakespeare, Moliere, and other playwrights who can be read from multiple perspectives. In the case of Nelson, the possibilities of exploration seem to me even greater, because most of his texts are still immersed in controversy. (Encenações 166)

Despite the controversies engendered by Rodrigues's play of oppositions, contradictory viewpoints, and confusing categories, Magaldi attempted to classify the author's plays, though not without sparking some controversy. For her part, Angela Leite Lopes has delineated the tragic aspects of Rodrigues's plays. She describes his work as a manifestation of a multitude of structural and thematic tragic elements, but with a particularly unexpected modern twist. She 
Grevan

sees his texts imbued with a "fresh force of becoming" (por-fazer) as the performance of the texts unfold, especially taking into account their power to above all surprise, shock, and disgust the typical conservative audience. This "becoming" refers to the possibility of meaning contained in many of the elements in his theater, such as in objects, parts, silences and words. This possibility is not easily revealed since it requires the staging technique for it to be enacted. In Filho's 1990 production of Os Sete Gatinhos, Silene wears a dress that covers her whole body in the front (as long as her posture is curved), but reveals a frail bare back when she turns it to the audience. What causes shock at first may subsequently prove trivial and cliché later on, often following circular trajectories.

Following Leite Lopes's lead, I would argue that Rodrigues's plays are gradually enhanced throughout their performance by means of a crescendo of tensions and intensity. This happens both in the dialogues and circumstances presented on stage by the maximum condensation of meanings stated or implied in any simple gesture or word, even when appearing to reflect mere clichés or commonplace trivia. Boots, white suits, umbrellas, coffins, vases, hands, wedding dresses, white suits and other seemingly unimportant objects gain more substance throughout the plays than the character themselves. Words, and above all, silences, left by unfinished words or dialogues, fill up the space with more intense emotional suspense than complete coherent sentences. As the plays proceed, what is generally considered to be ordinary slowly seems to acquire strange and often tragic qualities. Contrary to the Brechtian theatrical device of distancing applied for the spectators to think rationally about political and social issues, Rodrigues' theater provides an axis of melodrama to the dramatic text, causing both a distancing effect and an effect of empathy, catharsis mixed with gibe. Bibelot and Noronha, for example, both embody clichés; one of the malandro, and the other of the controlling patriarch, though they take on a strange-tragic-absurd-comedic intensity as the play unfolds.

Critics of Rodrigues's plays have attempted to understand them by studying Rodrigues's own commentaries on it. Henrique Buarque de Gusmão, for example, calls attention to Rodrigues's theatrical use of extreme passions, a type of technique of purification of humanity's base violent tendencies, presented in constant tension with the extremes of morality. Most importantly, Gusmão also states that it is in this commitment to the interplay of violence of human desires 
and the violence of oppression against the same desires that his theatricality rests, borrowing the Freyrian expression "equilíbrio de antagonismos" (97). Gusmão goes on to explore the intersections between Rodrigues and Freyre, describing how Rodrigues's theatricality is based on the Freyrian model of Brazilian social structures seen both from the colonial period when passionate violence ruled, and from the post-colonial period, when rigid morality was established (97). In turn, Guidarini calls this theatrical tension "a intercomplementaridade de opostos" (111), moving from one pole to the other through the interference of a third element. Contrary to Gusmão's emphasis on the Brazilian patriarchal family, Guidarini focuses his interpretation on larger themes of binary values such as hatred-love, light-dark, good-bad, also following the dual tension argument.

Many critics, including Gusmão and Guidarini, have taken as truth Rodrigues's own explanations for his "teatro desagradável." ${ }^{3}$ Furthermore, by exploring the extremes of human passion and morality, Rodrigues himself claimed he was purifying the audience through its subconscious identification with the darkest side of human behavior. Because of his vehement opposition to the leftist Marxist ideology dominant in Brazil at the time, and his tendency to create a persona for himself as author, it can be risky to use Rodrigues's own words to understand his theater. Given this, I wish to set aside Rodrigues's own hypothesis of purification and approach the idea of theatricality as a conflict between opposing forces linked to the device of fetishism.

According to Leite Lopes, in her brief analysis of Dorotéia and the play's character Das Dores:

. . . we will find here the shattering of the sense of character - until it becomes, literally, a thing. Nelson Rodrigues will finally propose to us a game on the current assertion that such an object, such scenic element, because it has an important role in the unfolding of the play, thus can also become a character. It is the whole operation of the theater, which is inserted here in this game. (208)

\footnotetext{
${ }^{3}$ Rodrigues first used this expression to describe his work after the performance of $O$ Vestido de Noiva in 1943.
} 
Grevan

All the elements contained in Rodrigues's theater, such as the multiple interpretations of stories being told on stage, the characters as cliché or archetype, the varying planes of reality, and the multiple objects/body parts, find themselves transformed into character-things. Given this, they acquire multiple and paradoxical meanings when imbued with tensions and become open to innumerable possible interpretations. This new proposition, according to which tensions are presented through the reification of elements on stage, does not necessarily negate the previous hypothesis; however, it adds another dimension to the author's theatrical devices. When there is the shared presence of different objects, words, and silences in a scene that not only oppose one another but confuse and sometimes dissolve their very oppositions, the work gains a postmodern and post-Freyrian twist. Although the family dynamic remains center-stage, mirroring Freyrian conceptions of the patriarchal family, this dynamic is superimposed by the interpersonal relationships that are ultimately narcissistic and destructive of family units. Furthermore, the world of the street and the society are always situated in this dynamic, discarding the hypothesis that the Brazilian family as interpreted by Freyre occupies center stage in any deeper sense. It is in this interpersonal, person-object and person-body that one is able to explore the author's commitment to theatricality while commenting on Brazilian society, going beyond family relationships as the dominant model. Put another way, the reification of multiple "things," combined with the author's emphasis on individual perversions, provides the engine for the device of fetishism in Rodrigues's theater.

Octave Mannoni illustrates the mindset of the fetishist, who thinks, for example: "I know very well that my mother does not have a penis, but I still want to pretend that she does and that this object is it." Mannoni wrote this paradoxical logic as: "je sais bien, mais quand-même" or "I know very well, but nevertheless...." Thus, the fetish is an object the very meaning of which contains two opposing forces within itself: that of recognition/acceptance and that of negation. The fetish is thus a structure that embodies the magical value and power of commodities with a sexual force - the female body being a particular focusdue to the male oriented gaze of the fetishist.

In the world of the play, fetishism acts first as a strategy by which the 
characters deal with silence, repression, and oppression; secondly, fetishism functions as a perverse form of agency; thirdly, fetishes are manifestations of an obsessive desire to compensate for a lack of power by dominating the other; and finally, fetishism is a theatrical device used in Rodrigues's theater to blend content and form.

There are elements of Rodrigues's theater that structurally contribute to the formation of the fetish as a formal device. As a playwright, Rodrigues is continuously forcing his audience to pay special attention to the execution and process of performance on stage. He is constantly reminding us of the artifices employed in a performance by revealing the stagecraft behind the play and never letting us completely forget that we are, indeed, watching a play. The fetish becomes an important element in this technique of distancing, since it maintains the obsessive attachments among the characters and between the audience and the play, despite the elimination of the fourth wall. By the fetishistic admission that one knows that a given object cannot fulfill her expectations and become the original object the inspired the desire in the first place, she creates both a distancing effect of detachment as well as an obsessive desire linking her to that object.

Characters such as Aurora and Bibelot in Os Sete Gatinhos, for example, ride in a cab and the author describes, in a stage direction parenthesis: "Bibelot estica as pernas. De vez em quando, os dois procuram sugerir o movimento do automóvel: carregam as cadeiras como se o táxi dobrasse esquinas, tirasse finos ou corresse em ziguezague" (793). In A Falecida, the author emphasizes the imaginary quality of the setting: "Numa mesa imaginária, dão tacadas, também imaginárias. O único dado realístico do ambiente é o taco" (935). Directors such as Antunes Filho were able to put this technique of both distancing and empathy on stage, by making this particular stage direction a highly stylized dance with music in the background.

In addition, another aspect, which adds to the structure of the fetish in the plays, is the imaginary societal mask. Characters are often aware of the different roles they might have to play depending on where they are in a scene, thus frequently creating dualistic types of personas, such as the saint or the prostitute, the gay man or the straight one, the moral husband or the scoundrel and so on. Although playing with opposite facets of themselves, the characters ultimately destroy the oppositions due to their repressive power to confine them into easily 
Grevan

acceptable categories. Silene, for example, destroys her good-girl image by committing acts that do not fit in neatly with any binary moral definitions of herself.

Rodrigues's emphasis on artificiality in his stage directions, the use of the media, the divided stage set denoting different reality planes, the multitude of possible stories about a character or dualistic roles, the performativity of everyday life, and the characters' single-minded obsessions, all mirror the fetishistic relationship. When entangled, the fetishistic relationship reveals a myriad of stories about the characters and the environment of the plays. As Robert J. Stoller affirms: "a fetish is a story masquerading as an object" (155). Thus, the explorations of objects, structures and characters as fetishistic helps us shed light into the performative aspects of the new Brazilian theater coming into being after Rodrigues in addition to the presence of these identical theatrical aspects within society itself.

In Os Sete Gatinhos, Silene internalizes the value of both virginity and pure love imposed on her by her family while acting out in a way that contradicts those same values. One may notice the juxtaposition of opposing, often opposed moral codes: ignoring the morality preached in her Catholic school, she beats a pregnant cat to death in front of the whole student body; and manipulating the idea of virginity imposed by religion, she has sex with her married lover while claiming to have actually found pure love. Characters such as Silene feel so much pressure from their families, their school, and society at large to behave in certain ways that they end up rebelling, while still clinging to those same values, albeit in a twisted manner. Silene's fetishistic relationship both to her lover Bibelot and the pregnant cat functions as a materialization of Silene's struggle, leading to the disturbing transformation of herself into a fetish with respect to her family.

The fetishistic relationship with the body of the other, whether with its parts or as an object, often appears as compensating for the power the characters are unable to obtain in the social sphere, that is, to go beyond static positions of societal power. Moreover, the complete lack of any profound sexual or even superficial love connection between and among the different characters is obvious. Each character takes as his or her love object or object of desire a projection of an egotistical desire, in total disconnect from the desire of the other. The "exchange value" of parts of the other are overvalued, not just monetarily, but ethically, religiously and socially, depending on their relational position in 
the world of the play. Silene's body in Os Sete Gatinhos, for example, is valued religiously and socially for its virginal status.

Deborah M. Horvitz, speaking of trauma and literature, describes the "repressive sociopolitical ideology of empowerment and disempowerment" that can serve "to confront an intensely destructive dynamic of sadomasochism" (4). In Rodrigues's plays, sadomasochism is reenacted on stage through fetishistic relations. Some of the power structures are kept in place through this duality, while some are reversed. The fetishism becomes even more crucial within this dynamic since violence is approached in a veiled, obscure manner through the fetishized object and the fetishistic relationship and is very rarely confronted directly. The intent of a fetish is three-fold: it conceals the problem of gender discrimination from view (since it is silenced by the object relationship); it affords sadomasochistic pleasure to both the victim and perpetrator; and it functions as a strategy for dealing with silence via a type of agency (i.e., the power to "own" the fetish). Silene's masochistic pleasure of having sex with an unattainable man reveals also the pleasure she takes in inflicting pain on her whole family while at the same time maintaining their investment in her as a fulcrum for their desires.

In Os Sete Gatinhos, the characters maintain exploitative relations in place with the excuse that the other is consenting. Silene's family, for example, hold her as their fetish with the belief that Silene actually enjoys being a symbol of purity for them, whereas the truth is at the opposite extreme of the spectrum. Ironically, following the same logic that justifies her isolation from men and society, Silene creates her own code of conduct and her own fetishes, all of which end up clashing with her family's expectations.

Silene's body, and the implications of what has been done to and with "it," gains a magical or superstitious value. It is the father's belief that her body has lost its virginal status due to a curse cast upon the family. Her body is also adored as an object of devotion, since all the members of the family believe Silene's virgin body guarantees her expensive marriage in a church. The marriage of a virgin would provide the whole family's salvation. Silene's body as pure and virginal also becomes an object of indirect sexual gratification, interfering with all the characters' sexual and love life, be it through the complete irrational desire it inspires, against any moral code and be it through the irrational actions of her father having all his daughters work as prostitutes. 
Grevan

Since the central focus of many of Rodrigues's plays are family dynamics, it is important to look at the variety of perspectives with which Os Sete Gatinhos deals. We might assume that the father, Seu Noronha, presents as a decadent paternal figure trying to maintain control by projecting power over his family because of his low class status, for which he is desperately trying to compensate. $\mathrm{He}$ is also a caricature of the gradually declining importance of this type of patriarchal family structure in view of the new gender dynamics coming into play, reflective of changing times. This is important, since it denotes contrary forces and movements, exemplified by the rigidly controlled energy attributed to all the characters on stage who often act as if they are about to explode whether emotionally or physically at any moment. However, it can be argued that among the lower socio-economic strata of urban families, the patriarchal family was not, in fact, predominant. That is perhaps why Rodrigues makes a point of transforming the patriarch into a pathetic, tragic, and disrespected figure anxiously clinging to a power he has never actually possessed, manifesting what could be called self-fetishistic anguish.

Seu Noronha attempts to "restore" the patriarchal fetish by means of violence and a masquerade of self-deluding anguish. He is the family patriarch, or he seems to be this, largely through a persistent effort to transform himself into a fetish for the other family members. He knows he does not hold this power in society or even in his home, so he creates and performs the fetishistic scenario of himself as a patriarch with supernatural abilities.

Considering the multitude of possible roles and identities that present themselves in Brazilian society, a well-defined power structure might be present in the higher socio-economic strata of society in addition to the lower echelons of street politics, but not necessarily in the home, as is very clearly delineated in the play. These two types of co-existing power structures (in the case of Seu Noronha, lower class in society in one place, "powerful" in the home, hopeful of ascending through his daughter's virgin marriage in the world of the beyond) create anxiety-riddled, confusing gender roles and dynamics whenever individuals pass from one sphere to another as from the home to the school to the street to the workplace and place of worship, to the world of the beyond. The daughters change masks depending where they are; prostitutes in some spheres, respectable governmental employees in others, lovers in another, girls at home, saved creatures in the world of the beyond through the virginity of their sister. 
The wife and daughters in the play are certainly not afraid to confront the father on occasion in opposition to their stated moral beliefs, and, contrariwise, seem to have an intense urge to free themselves from his overpowering need to control.

Mariza Correa has argued that the model of the patriarchal, agrarian family is not necessarily indicative of lived realities in colonial Brazil:

É possível reduzir a imensa gama de possibilidades inscritas num espaço natural e social aberto, muito lentamente ocupado e organizado, a uma historia a qual, mudando os personagens, permanece uma fala central idêntica a si mesma, preenchida a cada geração por novas palavras, sempre com o mesmo sentido? É possível ignorar a soma de personagens, funções e a mobilidade envolvidos na mais simples operação social no Brasil em seus primeiros anos de existência, e aprisionar todos estes elementos num lugar privilegiado como modelo de interação social: o engenho? É possível esquecer as redes de relações, as ramificações interior e exteriores ao país, necessárias a sobrevivência do mais simples estabelecimento colonial e incorporá-las todas na figura de um senhor, o dono do engenho-que muitas vezes não passava de um agente dos donos reais-, moderno Abraão conduzindo um dócil rebanho? (17)

Highlighting this controversial view of the Brazilian family is relevant here since Rodrigues's characters are always contesting traditional family values, or they belong to families that are on the verge of exploding under the pressures of their lives, or as women on the brink of emancipation. Rodrigues is accentuating the destruction and decadence of a system that has since become immovable, as well as bringing to light the possibility that different forms of family life have already been in existence. Furthermore, he is underscoring the characters' confusion visà-vis a system that accepts all these configurations without giving preference to any one of them in particular.

Os Sete Gatinhos brings to light the "memory" and the tradition of viewing the patriarch as an immovable cultural figure while at the same time squashing it. The myth of the patriarchal family is erected, but only as a fetish. Through fictional means, he is also exploring in what ways this patriarchal voice as wells as its myth could be a catalyst for destruction, oppression, and chaos, as opposed to being a bearer of peace and order. 
Grevan

The female characters in Os Sete Gatinhos are all deeply involved in a system of commerce that portrays them as sexual objects (and thus fetishes) whose value is defined by the male gaze in a society at least superficially imbued with patriarchal family values and Catholic mores. Silene's body, for example, is a clear example of an object marked by the imprint of virginity as an ideal, which is then fetishized by the rest of the family. The male protagonists objectify the female bodies, elevating them to a state of adoration, particularly whenever the female body is associated with virginity and purity. This is particularly oppressive since in the world of the plays sexuality is such a powerful attractive force, as well as a means for a series of exchanges. After deciding to quit his job, Seu Noronha proclaims: "Quem tem filhas bonitas não precisa ser continuo!" (872). Nonetheless, it is not the male, patriarchal gazes alone that fetishizes female bodies. The female characters themselves, as objects and subjects of desire, also actively perform fetishistic behavior.

The principle of commodification of many social elements in this economic system (in practice, literally everything seems to have an exchange value, e.g., the daughters' sexuality, Aurora's boyfriend, Silene, the trousseau, the curse etc.) varies according to which particular principles are taken into account. Silene's body is valued as the embodiment of the state of virginity that could be exchanged for salvation. The wedding dress and trousseau are representations of an illusory sanctity and, at the same time, the hypocrisy of marriage as a social institution used in exchanged for both salvation in the after-life as well as for buying a higher social status. In contrast, the mother's body is seen by the patriarch as grotesquely overweight and undesirable while being violently manipulated in exchange for ego boosting. Noronha uses his body spatially on the stage as messenger, martyr, and torturer. From this perspective, the body is extirpated of any meaning beyond its exchange value as a commodity, i.e., a commodity in exchange for certain "values", which in turn, ends up debasing all ethical considerations to the same level playing field. The prostitution of the four sisters likewise has an exchange value within the social sphere. So much so that the father believes their prostitution can be equitably exchanged for the Christian moral approval acquired through the marriage of the virgin sister.

Employing illicit monetary gain to attain social mobility is illusory at the outset in accordance with the logic that makes the fetish possible, i.e., the fetish contains contradictory meanings and values within itself. Even though the sisters 
do have normal day jobs, their real profession is prostitution, and their father uses all his contacts to find them clients. This would mean that even though the sisters "know that" the money they will save through prostitution to pay for Silene's wedding will not ultimately give them access to a higher social class; “... even so", they are willing to keep on fetishizing this unattainable goal. Thus, in that economic system, the daughters would always be stigmatized by the exchange and sale of their bodies and would never effectively benefit morally or socially from Silene's marriage.

As an addendum to Silene's virgin body, the trousseau has more paradoxical characteristics, being seen as a very powerful fetish disguised as representing a desire for religious salvation. The trousseau represents the hope harbored by the entire family they will be spared having to pay the price for all the sins they might have committed over their lifetimes. But, contrary to true religious or spiritual salvation, this family's must be purchased and paid for in cash. These characters are so severely disconnected from honest human relationships with which the hierarchical structures could be more seriously contested or analyzed, that the trousseau ends up becoming one more object among many in their theater of fetishistic commodities. It slowly gains a mystical fetishistic significance in that it is imbued with a value agreed upon by the whole family. Moreover, the value of marriage, virginity, and the trousseau are tied to the value of social appearances to a much greater extent than they would be if the marriage had been contracted solely on religious convictions. Seu Noronha affirms: "Vocês viraram prostitutas para dar um casamento de anjo a Silene. .." (868).

For Freud, female fetishism is quite rare. In taking Bibelot as their fetishized object, both Aurora and Silene reveal their defiance of their formerly passive position as mere mirrors of male desire. Besides the objects that are valued by virtue of the male gaze in addition to what I have called the patriarchal economy prevalent in Brazilian society at the time, it is clear that the female characters are also seeking their own agency and power through the fetishization of the other. According to Freud, and, in part, to Lacan, fetishists are almost all male since the anxiety of castration (even in the material imaginary of the penis-phallus) establishes itself much more intensely in men.

In this context, the fetishization of objects by the female characters in the play would mark an important contestation against hen-current gender norms. Silene loves Bibelot, fetishizing "the man dressed in white," even after learning 
Grevan

he is married (but before learning of Aurora's love for him). Bibelot is imbued with a religious value despite perfectly fitting the malandro stereotype. Silene is less aware of his deceitful behavior since she is convinced he has devoted his life to his sickly dying wife. She knows he is married and has had no scruples about him "robbing" her of her virginity. In turn, Aurora desires him even more now, due both to his "bad boy" behavior and to the fact that he does not shell out money for the "serviço completo" (834). Aurora says to Bibelot: "E tarei, não sei se por você, se pelo terno branco, sei lá" (835), at the opening of the play, thus revealing the strange relationship she has established with Bibelot and his suit. Not incidentally, the word "bibelot" itself signifies an object without true value, being merely decorative, a perfect fetish.

In Aurora's case, fetishism as an embodiment is unexpectedly turned into a tool for the women of the family. In turn, the body as object must embody a male figure to be able to destroy the overbearing, destructive patriarch, making it impossible for the women to obliterate the patriarchal family structure without feeling forced to embody the patriarchal figure themselves. It occurs that the other five female figures also regard Silene's virgin body as the ultimate fetish. Seu Noronha fetishizes the members of his family to compensate for his diminished role in society. The women, in turn, create fetishes to protest their submissive positions in all spheres of their lives. Furthermore, the ambiguous character of the fetish and the fetishist is revealed by the psychic sister who reincarnates her dead cousin. The instant the women of the family murder the patriarch, Aurora internalizes two simultaneous voices: a male voice of hate representing a dead male cousin's and another of a daughter-object rebelling against her father's power.

It is also important to emphasize the myriad of unique roles Aurora's body as incarnation plays in relation to the different members of her family, even with respect to her father, who in the end becomes a victim of his own fetishistic obsessions. Aurora's body as fetish turns on him since it ultimately cannot be controlled. Even though the father tries to spread his own fetishism to the other family members by constantly reenacting the fetishistic scenario, there is no constancy or sameness in the way the reenactments occur so the women remain beyond his control until the end.

Rodrigues goes beyond simply showing what is behind the duality of outside and inside, to reveal what passes through, what is ingrained versus what can be 
perceived when viewed through critical eyes in the fetishistic manifestations. Despite exploring familiar dualities such as how one is expected to behave against how one actually does behave, outside versus inside the home, or the mask representing the good girl versus the prostitute within the same woman, for example, Rodrigues never ends his plays with any clear revelations (such as "the truth of this character is revealed when we show her feelings behind closed doors, her "inner prostitute" or "her unconscious desires are repressed and revealed in the plays in such a way" type of assertions). The characters' struggles within society and at home are constantly intermingling in unexpected and unusual ways, proving to be more complex, ambivalent and multifaceted than could be resolved by the deciphering of simple dualities or monitoring the shedding of a myriad of identities. Silene's repressed desires, seen as a type of purification for the audience (in Rodrigues's explanation), is never revealed as being a representation of the opposite facet of virginity and purity. Furthermore, it expresses itself less as a repressed desired and more as the girl's "natural" development as a woman. In turn, the way it is expressed, used, thought and manipulated gain dimensions which are all connected to the character's relationships within the play. Her sexuality reveals more than the tension between morality and sexuality, since it shows a level of sexual awareness and freedom, which is more complicated than the idea of a highly repressive society to explain the environment of the play.

The play replicates and expands our vision of the politics of the body, sexuality, gender and family dynamics in Brazilian society. Rodrigues was able to question the fetishism of belief systems by exposing a variety of family dynamics, the pathetic nature of the patriarch and the prevalent underlying attitudes towards female bodies based on the same mythologies, conflicting ideas and a myriad of lifestyles co-existing in the city of Rio de Janeiro during his time. His work has made contributions in defining and examining the ways fetishism condenses much of what is connected to national narratives and discourses of identity to a variety of fields. In this play, Rodrigues unties that knot by exaggerating the differences, exposing the structures of power, intensifying the underlying social tensions as well as exposing the relational structures of fetishistic contracts which serve to perpetuate, mask, confuse, expose and give agency, all at the same time. 
Grevan

\section{Works Cited}

Almeida, Angela Mendes de. “Textos Seminário Família.” U de São Paulo. 2001. Web. 1 Sept. 2010.

Britton, B. Campbell. “Antunes Filho's Prismatic Theatre: Staging Nelson Rodrigues and Brazilian Identities." Dissertation, UCLA. Los Angeles: ProQuest, 2008. Web.

Butler, Judith. Gender Trouble: Feminism and the Subversion of Identity. New York: Routledge, 1990. Print.

Carlson, Marvin A. Performance: A Critical Introduction. London: Routledge, 1996. Print.

Caruth, Cathy. Trauma: Exploration in Memory. Baltimore, MD: Johns Hopkins UP, 1995. Print.

Castro, Ruy. O Anjo Pornográfico: A Vida de Nelson Rodrigues. São Paulo: Companhia das Letras, 1992. Print.

DaMatta, Roberto. A Casa \& A Rua: Espaço, Cidadania, Mulher e Morte no Brasil. São Paulo: Brasiliense, 1985. Print.

Freyre, Gilberto. Casa-Grande \& Senzala: Formação da Família Brasileira sob o Regime da Economia Patriarcal. Rio de Janeiro: Olympio, 1977. Print.

Freud, Sigmund. "Some Psychological Consequences of the Anatomical Distinction Between the Sexes." Sexuality and the Psychology of Love. Ed. Philip Rieff. New York: Collier, 1963. 183-93. Print.

-. "Fetishism." The Standard Edition of the Complete Psychological Works. Ed. and trans., James Strachey, et al. London: Hogarth, 1953-74. 149-57. Print.

Garber, Marjorie. "Fetish Envy." October 54 (1990): 45-56. Print.

Guidarini, Mário. Nelson Rodrigues: Flor da Obsessão. Florianópolis: UFSC, 1990. Print.

Gusmão, Henrique Buarque de. "Nelson Rodrigues leitor de Gilberto Freyre: o projeto teatral rodriguiano em aliança com a Sociologia freyreana." Soc. Estado. 23-1, p. 89-112. 2008. Web.

Kaplan, Louise J. Cultures of Fetishism. New York: Palgrave Macmillan, 2006. Print.

Lacan, Jaques. Ecrits. Trans. Bruce Fink. London: Norton, 1989. Print.

Lins, Ronaldo Lima. O Teatro de Nelson Rodrigues: Uma Realidade Em Agonia. Rio de Janeiro: Alves, 1979. Print. 
Lopes, Angela Leite. Nelson Rodrigues: Trágico, então Moderno. Rio de Janeiro: U Federal do Rio de Janeiro, 1993. Print.

Magaldi, Sábato. Nelson Rodrigues: Dramaturgia e encenações. São Paulo: Perspectiva, 1987. Print.

Mannoni, Octave. Clefs Pour l'Imaginaire; Ou, L'Autre Scène. Paris: Seuil, 1969. Print.

Marx, Carl. Capital. London: Lawrence and Wishart, 2003. Print.

Pietz, William. "The Problem of the Fetish, II: The Origin of the Fetish." RES 13 (1987): 23-45. Print.

Rodrigues, Nelson, and Sábato Magaldi. Teatro completo. Rio de Janeiro: Nova Aguilar, 2003. Print.

Schor, Naomi. "Female Fetishism: The Case of George Sand." Poetics Today 6.1-2 (1985): 301-10. Print. 